\title{
Effect of Supplementing Different Levels of Peppermint Powder on Production Performance of Broilers
}

\author{
S. Mohanty ${ }^{1}$, B. Panigrahi ${ }^{1}$, L. K. Babu ${ }^{1}$, K. Behera ${ }^{1 *}$, S. M. Nanda ${ }^{2}$ and G. P. Sabat ${ }^{1}$ \\ ${ }^{1}$ Department of Livestock Production and Management, College of Veterinary Science \& \\ Animal Husbandry, OUAT, Bhubaneswar-751003, India \\ ${ }^{2}$ Department of Veterinary \& Animal Husbandry Extension, College of Veterinary Science \& \\ Animal Husbandry, OUAT, Bhubaneswar-751003, India \\ *Corresponding author
}

A B S T R A C T

\begin{abstract}
Keywords
Peppermint powder, production performance, broilers

Article Info

Accepted:

20 January 2020

Available Online:

10 February 2020

Different strategies are being followed to enhance the body growth and economize the poultry feed. Use of peppermint powder is one such approach. This research work consisted of a total number of 160 day-old broiler chickens (Gallus gallusdomesticus) of vencobb strain were taken and the experimental birds divided into 4 treatment groups viz. $\mathrm{T}_{1}$ (control), $\mathrm{T}_{2}, \mathrm{~T}_{3}$ and $\mathrm{T}_{4}$ with two replicate in each treatment group, having 20 broiler chickens in every replicate in a complete randomized design. Birds supplemented with peppermint leaf powder showed higher body weight and FCR as compared to control group. The birds supplemented with $0.5 \%$ of peppermint leaf powder had the best FCR and was found to be economical.
\end{abstract}

\section{Introduction}

India is world's fifth largest egg producer and the eighteenth largest producer of broilers. Driving this kind of expansion the contributing factors are - growth in per capita income, a growing urban population and falling poultry prices. The use of phytogenics as feed additives is gaining importance due to their antimicrobial and stimulatory effects on digestive system (Jamroz et al., 2005; Jang et $a l$. , 2004). They include herbs, spices or plants that are used to keep the gut microflora of poultry normal, which is a prerequisite for cost efficient and ecofriendly poultry production (Windisch and Kroismayr, 2008.

Mentha piperita (Lamiaceae), the peppermint (mint) plant is an aromatic perennial herb cultivated in most part of the world, have traditionally been used in folk medicine. Peppermint (Mentha piperita L.) is widely used in herbal medicine and is believed to be particularly beneficial in building the immune 
system, and for its antimicrobial and strong antioxidant properties, as well as in its ability to enhance appetite, mainly due to its active components (Dorman et al., 2003). Feeding of Fish silage at $5 \%$ level proves to be economical for growth of broiler Japanese quail (Mohanty et al., 2020). Durrani et al., (2008) conducted a research in broiler by supplementation of Habek mint in feed at the rate of 5 (group A), 10 (B) and $15 \mathrm{~g} / \mathrm{kg}$ (c) and group D was kept control and concluded that feeding habek mint @ 15g/kg feed, highest gross return of the broilers.

\section{Materials and Methods}

This research work was carried out at
Instructional Livestock Farm Complex and Department of Livestock Production and Management, College of Veterinary Science and Animal Husbandry, OUAT, Bhubaneswar, Odisha.

A total number of 160 day-old broiler chickens (Gallus gallusdomesticus) of vencobb strain were taken and the experimental birds divided into 4 treatment groups viz. $\mathrm{T}_{1}$ (control), $\mathrm{T}_{2}, \mathrm{~T}_{3}$ and $\mathrm{T}_{4}$ with two replicate in each treatment group, having 20 broiler chickens in every replicate in a complete randomized design. The dietary management were as follows:

Table.1 Experimental design

\begin{tabular}{|c|c|}
\hline Groups & Dietary treatment \\
\hline $\mathbf{T}_{1}($ Control): & Basal diet \\
\hline $\mathbf{T}_{2}:$ & Basal Diet+0.1\% peppermint powder \\
\hline $\mathbf{T}_{3}:$ & Basal Diet+0.3\% peppermint powder \\
\hline $\mathbf{T}_{4}:$ & Basal Diet+0.5\% peppermint powder \\
\hline
\end{tabular}

Processing of experimental peppermint powder

Purchase of Fresh peppermint herbs from local market

Washed and dried under sun for 4-5 days

Collection of only the dried peppermint leaves

Dried leaves ground to powder

Peppermint powder packaged for use

The chickens were weighed group wise by top pan electronic weighing balance nearest to $1 \mathrm{~g}$ accuracy in each week up to the end of $5^{\text {th }}$ week were recorded. Daily feed offered to the birds were recorded group wise. The group average feed consumption was calculated by 
subtracting the left over feed at the end of each week from the total feed supplied to the birds during the said weeks. Cumulative feed consumption was calculated by adding the feed consumption from $1^{\text {st }}$ week up to the desired week.

Feed conversion ratio $=\frac{\text { Feed consumption in gram up to a particular week }}{\text { Body weight gain in gram uptothat week }}$

All the data generated in the above experiments were statistically analysed using
IBM SPSS 22.0computer package. For comparison of groups, Generalized Linear Model, ANOVA procedure and Duncan's multiple range tests were used.

\section{Results and Discussion}

The effect of feeding different levels of dried peppermint leaves powder on the body weight of the experimental birds is presented in Table 2.

Table.2 Average weekly body weight (g) of the experimental broiler birds under different dietary treatments

\begin{tabular}{|c|c|c|c|c|}
\hline Age & $\mathbf{T}_{\mathbf{1}}$ & $\mathbf{T}_{\mathbf{2}}(\mathbf{0 . 1 \%})$ & $\mathbf{T}_{\mathbf{3}}(\mathbf{0 . 3 \%})$ & $\mathbf{T}_{\mathbf{4}}(\mathbf{0 . 5 \%})$ \\
\hline $\mathbf{0}$ day & $42.50 \pm 1.41$ & $43.00 \pm 2.23$ & $43.50 \pm 1.58$ & $42.50 \pm 1.68$ \\
\hline $\mathbf{7}^{\text {th }}$ day & $143.66 \pm 3.12$ & $149.33 \pm 2.56$ & $152.16 \pm 2.18$ & $154.11 \pm 1.99$ \\
\hline $\mathbf{1 4}^{\text {th }}$ day & $424.00^{\mathrm{a}} \pm 6.47$ & $442.50^{\mathrm{a}} \pm 8.37$ & $448.66^{\mathrm{ab}} \pm 9.53$ & $462.72^{\mathrm{b}} \pm 7.12$ \\
\hline $\mathbf{2 1}^{\text {st }}$ day & $783.50^{\mathrm{a}} \pm 13.35$ & $809.50^{\mathrm{a}} \pm 11.88$ & $842.32^{\mathrm{ab}} \pm 13.25$ & $868.66^{\mathrm{b}} \pm 13.56$ \\
\hline $\mathbf{2 8}^{\text {th }}$ day & $1379.11^{\mathrm{a}} \pm 17.89$ & $1444.33^{\mathrm{b}} \pm 19.97$ & $1496.50^{\mathrm{c}} \pm 18.15$ & $1517.79^{\mathrm{c}} \pm 16.98$ \\
\hline $\mathbf{3 5}^{\text {th }}$ day & $1918.55^{\mathrm{a}} \pm 25.03$ & $1993.46^{\mathrm{b}} \pm 21.01$ & $2059.55^{\mathrm{c}} \pm 21.68$ & $2141.15^{\mathrm{d}} \pm 22.35$ \\
\hline
\end{tabular}

*Means bearing different superscripts differ significantly along the rows

There was no significant variation $(p>0.05)$ with respect to the mean day-old body weight and mean body weight on $7^{\text {th }}$ and $14^{\text {th }}$ day. The day-old body weight ranged from $42.50 \pm$ $1.41 \mathrm{~g}$ in $\mathrm{T}_{1}$ to $43.50 \pm 1.58 \mathrm{~g}$ in $\mathrm{T}_{3}$. On both $7^{\text {th }}$ and $14^{\text {th }}$ day, $\mathrm{T}_{4}$ birds had the highest body weight $154.11 \pm 1.99 \mathrm{~g}$ and $462.72 \pm 7.12 \mathrm{~g}$, respectively, though there was no statistical superiority.

Table.3 Average weekly body weight gain (g) of the experimental birds under different dietary treatments

\begin{tabular}{|c|c|c|c|c|}
\hline Week & $\mathbf{T}_{\mathbf{1}}$ & $\mathbf{T}_{\mathbf{2}}$ & $\mathbf{T}_{\mathbf{3}}$ & $\mathbf{T}_{\mathbf{4}}$ \\
\hline $1^{\text {st }}$ week & $101.16 \pm 4.67$ & $106.33 \pm 3.73$ & $108.66 \pm 3.69$ & $111.61 \pm 2.98$ \\
\hline $2^{\text {nd }}$ week & $280.34 \pm 4.31$ & $293.17 \pm 3.78$ & $296.50 \pm 3.04$ & $308.61 \pm 3.99$ \\
\hline $3^{\text {rd }}$ week & $359.50 \pm 3.77$ & $367.00 \pm 4.23$ & $393.66 \pm 4.33$ & $405.94 \pm 4.76$ \\
\hline $4^{\text {th }}$ week & $595.61 \pm 3.65$ & $634.83 \pm 4.12$ & $654.18 \pm 3.59$ & $649.13 \pm 4.98$ \\
\hline $5^{\text {th }}$ week & $539.44 \pm 4.92$ & $549.13 \pm 3.37$ & $563.05 \pm 3.86$ & $623.36 \pm 4.71$ \\
\hline
\end{tabular}

*Means bearing different superscripts differ significantly along the rows

On $21^{\text {st }}$ day, the birds under $\mathrm{T}_{4}$ showed the highest body weight $(868.66 \pm 13.56 \mathrm{~g})$, which was statistically significant $(\mathrm{p}>0.05)$ as compared to $\mathrm{T}_{1}(783.50 \pm 13.35 \mathrm{~g}), \mathrm{T}_{2}(809.50$ $\pm 11.88 \mathrm{~g})$ and $\mathrm{T}_{3}(842.32 \pm 13.25 \mathrm{~g})$. When the experimental birds attained $28^{\text {th }}$ day, the 
body weight of birds in $\mathrm{T}_{4}$ exhibited the highest body weight $\left(1517.79^{\mathbf{c}} \pm 16.98 \mathrm{~g}\right)$, which was significantly higher than the rest. Body weight of the birds under $T_{2}$ and $T_{3}$ were statistically comparable at $28^{\text {th }}$ day age $(1444.33 \pm 19.97$ vs. $1496.50 \pm 18.15 \mathrm{~g})$. At the end of the experiment on $35^{\text {th }}$ day, the birds from $\mathrm{T}_{4}$ had the highest body weight $(2141.15 \pm 22.35 \mathrm{~g})$, which was significantly higher $(\mathrm{p}>0.05)$ than $\mathrm{T}_{1}, \mathrm{~T}_{2}$ and $\mathrm{T}_{3}$. At this age, the body weights of the experimental birds under $\mathrm{T}_{2}$ and $\mathrm{T}_{3}$ did not significantly $(1993.46 \pm 21.01 \mathrm{~g} v s .2059 .55 \pm 21.68 \mathrm{~g})$.

The effect of feeding different levels of dried peppermint leaves powder on the weekly body weight gain of the experimental birds is presented in Table 3.

In the first week, the average body weight gain in all the treatment groups were statistically comparable ( $>0.05)$ ranging from $101.16 \pm 4.67 \mathrm{~g}$ in $\mathrm{T}_{1}$ to $111.61 \pm 2.98 \mathrm{~g}$ in $\mathrm{T}_{4}$. During the second week of the experiment, birds from $\mathrm{T}_{4}$ group had the highest body weight gain which was statistically superior $(p>0.05)$ to the $T_{1}$ i.e. control group. Though the body weight gain in $T_{4}$ group was numerically better than $T_{2}$ and $\mathrm{T}_{3}$, there was no statistical significance. During the third week of experiment, birds from $\mathrm{T}_{4}$ group showed statistically higher body weight gain $(405.94 \pm 4.76 \mathrm{~g})$ than rest three treatment groups. There was no statistically significant variation in the body weight gain of the birds under $T_{1}, T_{2}$ and $T_{3}$ groups. In the fourth week, a statistically higher ( $>0.05)$ body weight gain was observed in the birds from $\mathrm{T}_{3}$ group (654.18 \pm $3.59 \mathrm{~g})$ as compared to $\mathrm{T}_{1}(595.61 \pm 3.65 \mathrm{~g})$, $\mathrm{T}_{2}(634.83 \pm 4.12 \mathrm{~g})$ and $\mathrm{T}_{4}(649.13 \pm 4.98 \mathrm{~g})$. The difference in the body weight gain of the birds under $\mathrm{T}_{3}$ and $\mathrm{T}_{4}$ birds was not statistically significant $(\mathrm{p}>0.05)$, where the birds from $\mathrm{T}_{2}$ group had significantly higher (p>0.05) body weight gain than $\mathrm{T}_{1}$.

During the final i.e. fifth week of the experiment, the $\mathrm{T}_{1}$ birds had the lowest body weight gain (539.44 $\pm 4.92 \mathrm{~g})$ as compared the rest of the treatment groups, which was comparable to $\mathrm{T}_{2}(549.13 \pm 3.37 \mathrm{~g})$ and $\mathrm{T}_{3}$ $(563.05 \pm 3.86 \mathrm{~g})$ birds $(\mathrm{p}>0.05)$. During this period, the performance of the experimental birds under $\mathrm{T}_{4}$ group $(623.36 \pm 4.71 \mathrm{~g})$ was significantly higher $(\mathrm{p}>0.05)$ than $\mathrm{T}_{1}$ birds $(539.44 \pm 4.92 \mathrm{~g})$. The cumulative body weight gains of the experimental birds under different dietary treatments have been depicted in the Table 4.

Table.4 Average cumulative body weight gain (g) of the experimental birds under different dietary treatments

\begin{tabular}{|c|c|c|c|c|}
\hline Week & $\mathbf{T}_{\mathbf{1}}$ & $\mathbf{T}_{\mathbf{2}}$ & $\mathbf{T}_{\mathbf{3}}$ & $\mathbf{T}_{\mathbf{4}}$ \\
\hline $\mathbf{0 - 1}$ & $101.16 \pm 3.42$ & $106.33 \pm 4.03$ & $108.66 \pm 3.65$ & $111.61 \pm 4.67$ \\
\hline $\mathbf{0 - 2}$ & $381.50^{\mathbf{a}} \pm 4.91$ & $399.50^{\mathbf{b}} \pm 5.53$ & $405.16^{\mathbf{b}} \pm 5.86$ & $420.22^{\mathbf{c}} \pm 6.23$ \\
\hline $\mathbf{0 - 3}$ & $741.00^{\mathbf{a}} \pm 7.65$ & $766.50^{\mathbf{b}} \pm 8.66$ & $798.82^{\mathbf{c}} \pm 9.08$ & $826.16^{\mathbf{d}} \pm 10.31$ \\
\hline $\mathbf{0 - 4}$ & $1336.61^{\mathbf{a}} \pm 11.21$ & $1401.33^{\mathbf{b}} \pm 13.34$ & $1453.00^{\mathbf{c}} \pm 12.75$ & $1475.29^{\mathbf{c}} \pm 13.24$ \\
\hline $\mathbf{0 - 5}$ & $1876.05^{\mathbf{a}} \pm 15.26$ & $1950.46^{\mathbf{b}} \pm 17.73$ & $2016.05^{\mathbf{c}} \pm 16.33$ & $2098.65^{\mathbf{d}} \pm 17.71$ \\
\hline
\end{tabular}

*Means bearing different superscripts differ significantly along the rows.

The cumulative body weight gain up to second week (0-2 weeks) was significantly higher $(\mathrm{p}>0.05)$ in $\mathrm{T}_{4}(420.22 \pm 6.23 \mathrm{~g})$ and $\mathrm{T}_{3}(405.16 \pm 5.86 \mathrm{~g})$ as compared to $\mathrm{T}_{1}$
$(381.50 \pm 4.91)$ and $\mathrm{T}_{2}(399.50 \pm 5.53 \mathrm{~g})$ birds. The experimental birds under $\mathrm{T}_{4}$ group had significantly higher $(\mathrm{p}>0.05)$ cumulative body weight gain up to third week $(826.16 \pm$ 
$10.31 \mathrm{~g})$ as compared to rest three treatment groups. Similar result was also observed for the cumulative body weight up to fourth week, where it was significantly maximum $(\mathrm{p}>0.05)$ in $\mathrm{T}_{4}$ birds $(1475.29 \pm 13.24 \mathrm{~g})$, followed by $\mathrm{T}_{3}$ birds $(1453.00 \pm 12.75 \mathrm{~g}), \mathrm{T}_{2}$ $(1401.33 \pm 13.34 \mathrm{~g})$ and lastly $\mathrm{T}_{1}(1336.61 \pm$ $11.21 \mathrm{~g})$. The highest cumulative body weight up to fifth week observed in $\mathrm{T}_{4}$ treatment group (2098.65 $\pm 17.71 \mathrm{~g})$, which was significantly higher $(p>0.05)$ than rest three groups. The effect of supplementation of dried peppermint leaves powder on the weekly feed intake of the experimental birds under different treatment groups has been presented in Table 5.

Table.5 Average weekly feed intake $(\mathrm{g})$ of the experimental broiler birds under different dietary treatments

\begin{tabular}{|c|c|c|c|c|}
\hline Week & $\mathbf{T}_{\mathbf{1}}$ & $\mathbf{T}_{\mathbf{2}}$ & $\mathbf{T}_{\mathbf{3}}$ & $\mathbf{T}_{\mathbf{4}}$ \\
\hline $\mathbf{1}^{\text {st }}$ week & $331.85 \pm 11.21$ & $337.49 \pm 9.53$ & $339.32 \pm 10.23$ & $334.42 \pm 9.78$ \\
\hline $\mathbf{2}^{\text {nd }}$ week & $592.47 \pm 12.98$ & $609.46 \pm 12.99$ & $584.92 \pm 13.38$ & $641.92 \pm 12.11$ \\
\hline $\mathbf{3}^{\text {rd }}$ week & $619.18^{\mathrm{a}} \pm 15.23$ & $761.10^{\mathrm{c}} \pm 16.31$ & $726.71^{\mathrm{b}} \pm 15.88$ & $778.35^{\mathrm{c}} \pm 16.83$ \\
\hline $\mathbf{4}^{\text {th }}$ week & $1063.02^{\mathrm{a}} \pm 18.15$ & $1079.51^{\mathrm{a}} \pm 17.18$ & $1177.44^{\mathrm{b}} \pm 18.21$ & $1083.57^{\mathrm{a}} \pm 17.23$ \\
\hline $\mathbf{5}^{\text {th }}$ week & $1153.84^{\mathrm{d}} \pm 13.12$ & $980.08^{\mathrm{c}} \pm 14.99$ & $920.00^{\mathrm{b}} \pm 16.95$ & $865.92^{\mathrm{a}} \pm 15.65$ \\
\hline
\end{tabular}

*Means bearing different superscripts differ significantly along the rows.

The weekly feed for the first week was comparable $(\mathrm{p}>0.05)$ in all the treatment groups ranging from $331.85 \pm 11.21 \mathrm{~g}\left(\mathrm{~T}_{1}\right)$ to $339.32 \pm 10.23 \mathrm{~g}\left(\mathrm{~T}_{3}\right)$. During the second week, birds from $\mathrm{T}_{4}$ group consumed significantly higher $(p>0.05)$ feed when compared to $\mathrm{T}_{3}$ and $\mathrm{T}_{1}$ birds $(641.92 \pm 12.11$ vs. $584.92 \pm 13.38 \mathrm{~g}$ and $592.47 \pm 12.98$ respectively), but was not statistically different from $\mathrm{T}_{2}(609.46 \pm 12.99 \mathrm{~g})$ birds. During the third week of experiment, birds from $\mathrm{T}_{4}$ group showed significantly higher (p>0.05) feed consumption $(778.35 \pm 16.83 \mathrm{~g}$ ) as compared to rest three treatment groups. During fourth week, $T_{3}$ birds had significantly higher ( $\mathrm{p}>0.05$ ) feed consumption (1177.44 \pm $18.21 \mathrm{~g}$ ) followed by $T_{4}$ and $T_{2}(1083.57 \pm$ $17.23 \mathrm{~g}$ and $1079.51^{\mathrm{b}} \pm 17.18 \mathrm{~g}$, respectively) and lastly the $\mathrm{T}_{1}$ birds $(1063.02 \pm 18.15 \mathrm{~g})$. During the final week of the experiment i.e. the fifth week, the $T_{1}$ birds had significantly higher ( $p>0.05$ ) feed consumption (1153.84 \pm $13.12 \mathrm{~g})$ which was distinctly higher $(\mathrm{p}>0.05)$ than $\mathrm{T}_{2}(980.08 \pm 14.99), \mathrm{T}_{3}\left(920.00^{\mathrm{a}} \pm 16.53\right.$ g) and $\mathrm{T}_{4}\left(865.92^{\mathrm{a}} \pm 15.65 \mathrm{~g}\right)$ birds. Results are also in agreement with Athina et al., (2017) who recorded improved broiler chickens performance with the combined dietary supplementation with oregano, attapulgite and benzoic acid.

Table.6 Cumulative feed intake (g) of the experimental broiler birds under different dietary treatments

\begin{tabular}{|c|c|c|c|c|}
\hline Week & $\mathbf{T}_{\mathbf{1}}$ & $\mathbf{T}_{\mathbf{2}}$ & $\mathbf{T}_{\mathbf{3}}$ & $\mathbf{T}_{\mathbf{4}}$ \\
\hline $\mathbf{0 - 1}$ & $331.85 \pm 9.88$ & $337.49 \pm 9.25$ & $339.32 \pm 12.34$ & $334.42 \pm 9.22$ \\
\hline $\mathbf{0 - 2}$ & $924.32 \pm 13.86$ & $946.95 \pm 11.15$ & $924.24 \pm 15.12$ & $976.34 \pm 11.58$ \\
\hline $\mathbf{0 - 3}$ & $1543.50^{\mathrm{a}} \pm 20.34$ & $1708.05^{\mathrm{c}} \pm 17.92$ & $1650.95^{\mathrm{b}} \pm 18.58$ & $1754.69^{\mathrm{c}} \pm 16.83$ \\
\hline $\mathbf{0 - 4}$ & $2606.52^{\mathrm{a}} \pm 24.35$ & $2787.56^{\mathrm{b}} \pm 19.97$ & $2828.39^{\mathrm{bc}} \pm 17.87$ & $2838.27^{\mathrm{c}} \pm 18.01$ \\
\hline $\mathbf{0 - 5}$ & $3760.36 \pm 27.18$ & $3767.64 \pm 21.27$ & $3748.38 \pm 20.11$ & $3704.19 \pm 20.56$ \\
\hline
\end{tabular}


*Means bearing different superscripts differ significantly along the rows.

Cumulative feed intake of the experimental birds after supplementation of dried peppermint leaves powder at different levels is illustrated in Table 6.

Up to second week of the experimentation, cumulative feed intake was significantly higher $(\mathrm{p}>0.05)$ in $\mathrm{T}_{4}$ birds $(976.34 \pm 11.58$ $\mathrm{g})$, as compared to $\mathrm{T}_{1}(924.32 \pm 13.86 \mathrm{~g})$ and $\mathrm{T}_{3}(924.24 \pm 15.12)$ which are lower than $\mathrm{T}_{2}$ $(946.95 \pm 11.15 \mathrm{~g})$. The cumulative feed intake up to third week also showed significantly maximum intake by the $\mathrm{T}_{4}$ birds $(1754.69 \pm 16.83 \mathrm{~g})$ with respect to other three experimental groups. The trend continued for the cumulative feed intake up to fourth week, where the birds under $\mathrm{T}_{4}$

$(2838.27 \pm 28.01 \mathrm{~g})$ had distinctly higher feed intake in comparison to rest three treatment groups. But at the end of the experiment, the birds from $\mathrm{T}_{2}(3767.64 \pm 21.27 \mathrm{~g})$ and $\mathrm{T}_{1}$ $(3760.36 \pm 27.18 \mathrm{~g})$ had significantly higher cumulative feed intake as compared to $\mathrm{T}_{3}$ $(3748.38 \pm 20.11 \mathrm{~g})$ and $\mathrm{T}_{4}(3704.19 \pm 20.56$ g) birds.Alaeldein et al., (2013) also observed that feed intake was not significantly different among all treatments, with the addition of commercial essential oil blend, as an alternative to antibiotic in-feed. Cumulative FCR of the experimental birds in response to the supplementation of dried peppermint leaves powder at different level of inclusion has been depicted in Table 7 .

Table.7 Cumulative Feed Conversion Ratio (FCR) of the experimental broiler birds under different dietary treatments

\begin{tabular}{|c|c|c|c|c|}
\hline Week & $\mathbf{T}_{\mathbf{1}}$ & $\mathbf{T}_{\mathbf{2}}$ & $\mathbf{T}_{\mathbf{3}}$ & $\mathbf{T}_{\mathbf{4}}$ \\
\hline $\mathbf{0 - 1}$ & $2.31 \pm 0.06$ & $2.26 \pm 0.04$ & $2.23 \pm 0.05$ & $2.17 \pm 0.07$ \\
\hline $\mathbf{0 - 2}$ & $2.18 \pm 0.05$ & $2.14 \pm 0.03$ & $2.06 \pm 0.01$ & $2.11 \pm 0.04$ \\
\hline $\mathbf{0 - 3}$ & $1.97^{\mathrm{a}} \pm 0.02$ & $2.11^{\mathrm{b}} \pm 0.07$ & $1.96^{\mathrm{a}} \pm 0.04$ & $2.02^{\mathrm{ab}} \pm 0.06$ \\
\hline $\mathbf{0 - 4}$ & $1.89 \pm 0.08$ & $1.93 \pm 0.06$ & $1.89 \pm 0.03$ & $1.87 \pm 0.05$ \\
\hline $\mathbf{0 - 5}$ & $1.96^{\mathrm{c}} \pm 0.04$ & $1.89^{\mathrm{b}} \pm 0.05$ & $1.82^{\mathrm{ab}} \pm 0.07$ & $1.73^{\mathrm{a}} \pm 0.02$ \\
\hline
\end{tabular}

*Means bearing different superscripts differ significantly along the rows.

Up to fourth week, FCR did not vary significantly among all the treatment groups, whereas at the end of the experiment FCR of $\mathrm{T}_{4}$ birds was found to be significantly superior compared to $\mathrm{T}_{1}$ birds $(1.73 \pm 0.02$ vs. $1.96 \pm$ 0.04). The performance of the birds under $T_{2}$ and $\mathrm{T}_{3}$ birds did not vary statistically in comparison to either $\mathrm{T}_{1}$ or $\mathrm{T}_{4}$ groups. These results are also in agreement with Adil et al., (2011) who observed that birds fed with diet supplemented with organic acids showed a significant improvement in the FCR as compared to birds fed the control diet.
The economics of the experimental birds under different treatment groups up to fifth week of age are presented in Table 8. After the end of the experiment, all the birds were sold in the market with a sale price of Rs. 94.00 per live weight. Birds in the $\mathrm{T}_{4}$ group by virtue of its higher body weight and superior FCR had the highest profit of Rs. 19.51 per bird followed by $\mathrm{T}_{3}$ (Rs. 15.23), $\mathrm{T}_{2}$ (Rs. 13.33) and lastly the control $\mathrm{T}_{1}$ (Rs. 9.01). All the supplemented birds showed higher profit margin than the control birds. 
Table.8 Economics of the experimental birds' production under different dietary treatments

\begin{tabular}{|c|c|c|c|c|}
\hline Attributes & $\mathbf{T}_{\mathbf{1}}$ & $\mathbf{T}_{\mathbf{2}}$ & $\mathbf{T}_{\mathbf{3}}$ & $\mathbf{T}_{\mathbf{4}}$ \\
\hline Chick cost (Rs.) & 41.00 & 41.00 & 41.00 & 41.00 \\
\hline Feed consumed per bird (g) & 3760.36 & 3767.64 & 3748.38 & 3704.19 \\
\hline Feed cost @ Rs. 32/kg & 120.33 & 120.56 & 119.95 & 118.53 \\
\hline Peppermint leaf powder supplementation (g) & - & 3.77 & 11.25 & 18.52 \\
\hline Cost of Peppermint leaf powder @ Rs. 660/kg & - & 2.49 & 7.42 & 12.22 \\
\hline Miscellaneous cost (Rs.) & 10.00 & 10.00 & 10.00 & 10.00 \\
\hline Total cost (Rs.) & 171.33 & 174.05 & 178.37 & 181.76 \\
\hline Average weight (kg) & 1918.55 & 1993.46 & 2059.55 & 2141.15 \\
\hline Sale (Rs.) & 180.34 & 187.39 & 193.60 & 201.27 \\
\hline Profit (Rs.) & 9.01 & 13.33 & 15.23 & 19.51 \\
\hline
\end{tabular}

Birds supplemented with peppermint leaf powder significantly enhanced the body weight and FCR as compared to control group. The birds supplemented with $0.5 \%$ of peppermint leaf powder had the best FCR and was found to be economical. Thus, this can be used in broiler feeds to enhance its growth and make the feed economical.

\section{References}

Adil S., Banday T., Bhat G.H., Salahuddin M., RaquIb M., Shanaz S. Response of broiler chicken to dietary supplementation of organic acids. J Cent Eur Agric. 2011;12(3):498-508.

Alaeldein M. Abudabos, Emad M. Samara, Elsayeid O.S. Hussein, Mu'athQ.AlGhadi\&Raed M. Al-Atiyat (2013) Impacts of Stocking Density on the Performance and Welfareof Broiler Chickens, Italian Journal of Animal Science, 12:1, e11

AthinaTzora, IliasGiannenas, AchilleasKaramoutsios,

NikolaosPapaioannou et al., Effects of Oregano, Attapulgite, Benzoic Acid and their Blend on ChickenPerformance, Intestinal Microbiology and Intestinal Morphology, Journal of Poultry
Science. 2017; 54:218-227

Dorman, H. J. D., M. Kosar, K. Kahlos, Y. Holm, and R. Hiltunen. 2003. Antioxidant properties and composition of aqueous extracts from Mentha species, hybrids, varieties, and cultivars. J. Agric. Food Chem. 51:4563-4569

DurraniFr, Abidullah, Chand N, Durrani Z AndAkhtar S. 2008. Hematological, Biochemical, Immunomodulatory And Growth Promoting Effect Of Feed Added Wild Mint (MenthaLongifolia) In Broiler Chicks . Sarhad J. Agric, 24(4):661-664.

Jamroz, D., A. Wiliczkiewicz, T. Wertelecki, J. Orda, and J. Skorupinska. 2005. Use of active substances of plant origin in chicken diets based on maize and locally grown cereals. Br. Poult. Sci. 46:485-493.

Jang, I. S., Y. H. Ko, H. Y. Yang, J. S. Ha, J. Y. Kim, S. Y. Kang, D. H. Yoo, D. S. Nam, D. H. Kim, and C. Y. Lee. 2004. Influence of essential oil components on growth performance and the functional activity of the pancreas and small intestine in broiler chickens. Asian australas. J. Anim. Sci. 17:394-400.

Mohanty, A., L. K. Babu, B. Sahoo and Nanda, S. M. 2020. To Economize the 
Feed Cost of Broiler Japanese Quail (Coturnixcoturnix japonica) by Feeding Fish Silage. Int.J.Curr.Microbiol.App. Sci. 9(01): 722-726.

SPSS (Statistical Procedures for Social Sciences) 2019.SPSS User's guide version 22.0.SPSS Institute Inc., Cary
$\mathrm{NC}$

Windisch, W., K. Schedle, C. Plitzner, and A. Kroismayr. 2008. Use of phytogenic products as feed additives for swine and poultry. J. Anim. Sci. 86(E-Suppl.): E140-E148.

\section{How to cite this article:}

Mohanty. S, B. Panigrahi, L. K. Babu, K. Behera, S. M. Nanda and Sabat. G. P. 2020. Effect of Supplementing Different Levels of Peppermint Powder on Production Performance of Broilers. Int.J.Curr.Microbiol.App.Sci. 9(02): 2948-2955. doi: https://doi.org/10.20546/ijcmas.2020.902.336 